Original Research Paper

\title{
Rumah Belajar dan Program Pendidikan sebagai Usaha Peningkatan Kualitas Pendidikan di Desa Pare Mas Kecamatan Jerowaru
}

\author{
Muh. Zubair ${ }^{1 *}$, Riska Nurwarsilla ${ }^{2}$, Laily Aulia Yolanda ${ }^{2}$, Lalu Riki Gita Sukma ${ }^{3}$, Lina \\ Nuriyati $^{3}$, Fani Rizki Pebyani ${ }^{4}$, Safitri Melinia ${ }^{4}$ \\ ${ }^{1}$ Pendidikan Pancasila dan Kewarganegaraan, FKIP, Universitas Mataram, Mataram, Indonesia \\ ${ }^{2}$ Pendidikan Bahasa Indonesia, FKIP, Universitas Mataram, Mataram, Indonesia \\ ${ }^{3}$ Pendidikan Matematika, FKIP, Universitas Mataram, Mataram, Indonesia \\ ${ }^{4}$ Pendidikan Guru Sekolah Dasar, FKIP, Universitas Mataram, Mataram, Indonesia
}

https://doi.org/10.29303/jpmpi.v3i2.1399

Sitasi: Zubair, M., Nurwarsilla, R., Yolanda, L. A., Sukma, L. R. G., Nuriyati, L., Pebyani, F. R \& Melinia, S. (2022). Rumah Belajar dan Program Pendidikan sebagai Usaha Peningkatan Kualitas Pendidikan di Desa Pare Mas Kecamatan Jerowaru. Jurnal Pengabdian Magister Pendidikan IPA, 5(1)

\section{Article history}

Received: 11 Januari 2022

Revised: 01 Februari 2022

Accepted: 07 Februari 2022

*Corresponding Author: Muh. Zubair, Fakultas Keguruan dan Ilmu Pendidikan, Universitas Mataram, Mataram, Indonesia; Email: zubairfkip8@gmail.com

\begin{abstract}
Pendidikan di Desa Pare Mas merupakan pendidikan yang sangat minim akan keterbatasan sumber daya manusianya, sarana, dan prasarana maupun pengajarnya. Sehingga memungkinkan terjadinya suatu desa atau wilayah menjadi tehambat. Dalam artikel ini, menggunakan Metode penelitian deskriptif kualitatif. Program kerja yang dibentuk oleh mahasiswa KKN adalah pengajaran di sekolah, edukasi tanggap bencana, Peningkatan Kreativitas Anak Sekolah Dasar; Kerajinan Tangan, Pendampingan Class Meeting, dan Rumah Belajar yang terdiri dari Belajar Basic English, belajar matematika, belajar mengaji, dan belajar membaca. Hasil dari realisasi pengabdian pengajaran di Desa Pare Mas terlaksana dengan baik dan dapat berjalan dengan lancar dan mampu diterima oleh anak-anak Sekolah Dasar maupun anak-anak Sekolah Menengah Pertama di Desa Pare Mas.
\end{abstract}

Keywords: Pendidikan, Rumah Belajar, Desa Pare Mas

\section{Pendahuluan}

$\mathrm{P}$ endidikan merupakan sebuah wadah bagi semua orang dalam mengembangkan ilmu pengetahuan dalam situasi formal dan non formal. Pendidikan berkualitas merupakan harapan bangsa dalam mengembangkan kemampuan dan membentuk watak serta peradaban bangsa yang bermartabat dalam rangka mencerdaskan kehidupan bangsa. Pendidikan adalah bagian terpenting dari kehidupan manusia tak pernah ditinggalkan melainkan lebih merupakan bagian dari kehidupan yang memang telah berjalan sejak manusia itu ada. Sejalan dengan uraian di atas menurut Imam Barnadib, pendidikan adalah usaha sadar dan sistematis untuk mencapai taraf hidup atau kemajuan yang lebih baik.

Pentingnya suatu pendidikan apalagi di desa yang jauh dari hiruk pikuk perkotaan dan fasilitas sangat kurang memadai menjadi sebuah visi perguruan tinggi untuk mengabdikan diri kepada masyarakat secara langsung dalam memecahkan dan memberikan solusi atas masalah yang dihadapi di masyarakat. Salah satunya adalah masalah pendidikan.

Pendidikan di desa Pare Mas sendiri sangat minim akan keterbatasan sumber daya manusianya, sarana dan prasarana, maupun pengajarnya. Sehingga memungkinkan terjadinya penghambatan dalam perkembangan suatu desa atau wilayah. Keadaan yang terjadi di Desa Pare Mas, dengan berbagai mata pencaharian, diantaranya adalah nelayan dan Petani. Banyaknya orang tua yang sibuk dengan pekerjaan setiap harinya menyebabkan waktu untuk mengurus anak sangat terbatas begitu juga waktu mereka dalam mengurus pendidikan anak sehingga anak-anak di Desa Pare Mas banyak yang tidak bisa membaca-tulis. Berdasarkan observasi dan wawancara yang dilakukan, Bapak Sahman selaku Kepala Desa Pare Mas mengungkapkan bahwa keterbatasan ilmu pengetahuan membuat masyarakat lebih memilih 
putus sekolah dan memutuskan untuk bekerja dan menikah di usia dini dan kurangnya pemahaman akan pentingnya pendidikan sehingga rata-rata pendidikan masyarakat Desa Pare Mas hanya tamatan SMA.

Berdasarkan hal di atas mahasiswa KKN Terpadu Universitas Mataram membuat program Rumah belajar yang bertujuan untuk memberikan pengajaran, pengetahuan dan pemahaman dalam dunia pendidikan sekaligus sebagai wahana dalam mengabdikan keilmuanya kepada masyarakat di Desa Pare Mas Kecamatan Jerowaru.

Program kerja yang dibentuk adalah Rumah belajar dan program pendidikan merupakan salah satu Program kerja mahasiswa KKN Terpadu Universitas Mataram yang mempunyai dua jenis tahap pembelajaran yaitu tahap pembelajaran dilakukan di sekolah dan tahap pembelajaran dilakukan di lokasi Mahasiswa KKN Terpadu Unram 2021. Proses pembelajaran ini dibentuk dengan dua jenis pertama formal yaitu dilakukan di sekolah dengan mata pembelajaran Bahasa Indonesia, Bahasa Inggris, Matematika, Biologi. Sedangkan pada program pendidikan non formal dilakukan di lokasi KKN dengan berbagai bidang ilmu pengetahuan diantaranya belajar membaca, berhitung, dan mengaji.

Pengajaran di Sekolah diawali dengan kunjungan kepada masing-masing sekolah terdekat. Kemudian melakukan pendamping oleh mahasiswa KKN kepada siswaSekolah Dasar (SD) dan Sekolah Menengah Pertama (SMP). Karena sekolah tersebut sedang melakukan ulangan akhir semester sehingga proses pembelajar belum dilakukan, namun melakukan pendampingan dengan cara membantu guru-guru dalam mengawasi ulangan akhir semester. Setelah ulangan akhir semester selesai, mahasiswa KKN mengadakan lomba pada tiap tiap sekolah dengan berbagai mata lomba yang menarik dan tentunya mengasah kemampuan kognitif serta keterampilan siswa.

\section{Metode Pelaksanaan}

Metode pelaksana program pengabdian melalui kegiatan KKN ini menggunakan metode pendekatan partisipatif kolaborasi, yaitu melibatkan masyarakat dalam kegiatan. Pelaksanaan KKN pada tanggal 15 November s.d 6 Januari. Lokasi pelaksanaan KKN di Desa Pare Mas, Kecamatan Jerowaru, Kabupaten Lombok Timur. Adapun metode dan rancangan kegiatan pengabdian ini terdiri dari (1) Tahap awal yaitu menginformasikan program sekaligus meminta izin kepada Kepala Desa Pare Mas dan lembaga Pendidikan SD dan SMP. (2) Tahap pelaksanaan dan (3) Tahap Monitoring dan Evaluasi. Program kegiatan pengabdian melalui KKN ini dilaksanakan sesuai potensi yang ada di Desa Pare Mas, Kecamatan Jerowaru, Kabupaten Lombok Timur.

\section{Hasil dan Pembahasan}

\section{1) Pengajaran di Sekolah}

Pengajaran di sekolah adalah salah satu program yang diangkat oleh kelompok KKN Terpadu Universitas Mataram di Desa Pare Mas sebagai bentuk perwujudan Tri Dharma Perguruan tinggi yaitu pendidikan dan pengajaran. Pengajaran dilaksanakan di sekolah yang berada di Desa Pare Mas. Adapun sekolah-sekolah yang terletak di Desa Pare Mas adalah SDN 1 Pere Mas, SDN 2 Pere Mas, dan SMP Islam Terpadu Ryadussholihin. Adapun beberapa program kerja yang dilaksanakan di sekolah-sekolah tujuan sebagai berikut:

a) Edukasi Tanggap Bencana

Edukasi tanggap bencana ditujukan untuk siswa di SDN 2 Pere Mas yang dihadiri oleh siswa kelas 1 sampai dengan kelas 6 dan dilaksanakan di Aula SDN 2 Pere Mas. Edukasi tanggap bencana disampaikan langsung oleh mahasiswa KKN Terpadu Unram 2021.

Edukasi tanggap bencana bertujuan untuk memberikan pemahaman terhadap siswa-siswi di SDN 2 Pere Mas tentang langkah-langkah awal penyelamatan jika terjadinya bencana alam. Hal ini akan sangat bermanfaat untuk siswa-siswi agar dapat mencegah terdapatnya korban bencana alam akibat kepanikan yang berlebihan. Selain langkah awal penyelamatan. Edukasi tanggap bencana juga akan memberikan pengetahuan bagaimana ciri-ciri bencana alam yang terjadi dan segala hal yang harus dilakukan setelah terjadinya bencana alam. Edukasi bencana alam yang disampaikan kepada siswa-siswi SDN 2 Pere Mas adalah bencana gempa bumi, bencana gunung meletus, Tsunami, banjir, longsor dan angin puting beliung. Selain memberikan pemahaman tentang tanggap bencana alam mahasiswa KKN Terpadu Unram juga memberikan hadiah kepada siswa-siswi yang dapat menjawab pertanyaan mengenai bencana alam yang telah disampaikan sebelumnya. Terdapat 6 siswa-siswi SDN 2 Pere Mas yang terpilih untuk menjawab 6 soal yang ditanyakan oleh pemateri. Pertanyaan yang diberikan dapat dijawab sepenuhnya sehingga dapat diketahui 
bahwa peserta edukasi sudah dapat memahami penyampaian yang diberikan terkait mitigasi bencana

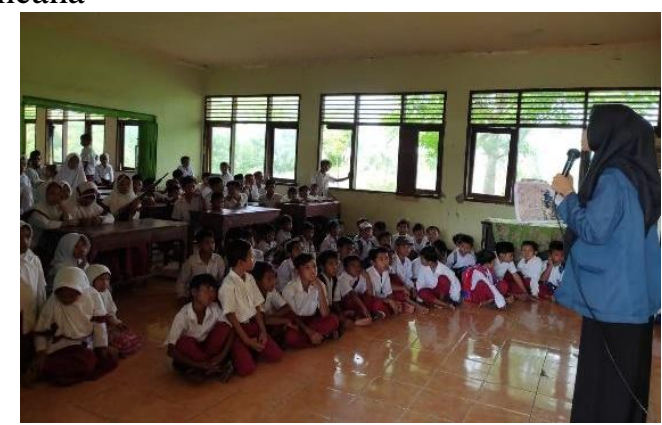

Gambar 1 Kegiatan Edukasi Tanggap Bencana di SDN 02 Pere Mas

\section{b) Peningkatan Kreativitas Anak Sekolah Dasar}

Kegiatan in merupakan salah satu program pendidikan yang dilaksanakan oleh KKN terpadu unram 2021. Pelaksanaan peningkatan kreatifitas ini dilaksanakan di SDN 2 Pere Mas dengan diikuti oleh siswa-siswi pilihan dari pihak guru di sekolah dengan kriteria tertentu dikarenakan adanya keterbatasan alat dan bahan yang harus dimiliki oleh siswa sebelum mengikuti kegiatan kreatifitas yang didampingi oleh mahasiswa KKN terpadu Unram 2021. Adapun kegiatan peningkatan kreatifitas yang dilaksanakan oleh mahasiswa KKN terpadu Unram 2021 adalah sebagai berikut:

1. Lomba Mewarnai

Lomba mewarnai adalah salah satu kegiatan yang dilaksanakan untuk meningkatkan kreativitas anak di SDN 2 Pere Mas. Lomba mewarnai diikuti oleh 26 orang siswa yang berasal dari kelas 1,2, dan 3. Gambar yang akan diwarnai telah disiapkan sebelumnya oleh mahasiswa KKN terpadu Unram 2021 sekaligus sebagai panitia pelaksana kegiatan. Gambar yang disiapkan juga memiliki tingkat kesulitan yang berbeda-beda dikarenakan dalam lomba mewarnai terdapat 3 tingkatan kelas yang berbeda. Selain menyediakan gambar, panitia juga menyediakan pensil warna bagi siswa yang tidak memiliki alat mewarnai. Lomba mewarnai dilaksanakan di ruang kelas 1a di SDN 2 Pere Mas. Pelaksanaan lomba mewarnai dilaksanakan selama 2 jam yang didampingi oleh mahasiswa KKN Terpadu Unram 2021.

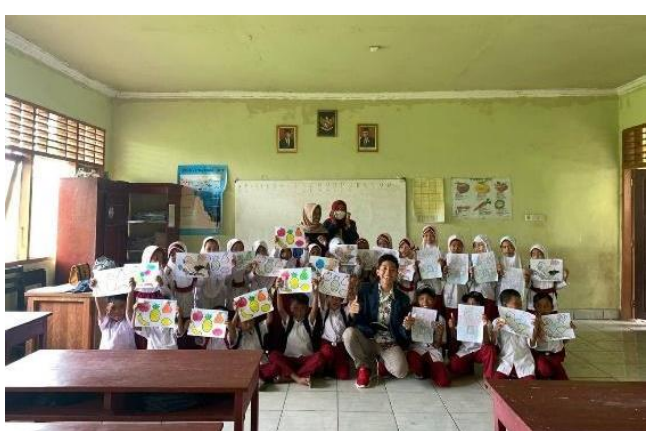

Gambar 2 Kegiatan Lomba Mewarnai

2. Kerajinan Tangan

Pembimbingan pembuatan kreativitas yang dilaksanakan oleh mahasiswa KKN terpadu unram 2021 adalah pembuatan kerajinan tangan. Pembuatan kerajinan tangan yang dilaksanakan di SDN 2 Pere Mas dan diikuti oleh 15 orang siswa perwakilan dari kelas 4, 5, dan 6 yang dibagi menjadi 3 kelompok. Setiap kelompok mendapatkan dua orang pembimbing dari mahasiswa KKN terpadu Unram 2021. Kerajinan tangan yang dibuat adalah pembuatan bunga menggunakan barangbarang bekas. Bahan-bahan yang digunakan adalah plastik berbagai macam warna, sedotan plastik, double tip dan kawat. Sedangkan alat yang digunakan adalah gunting. Siswa membuat kerajinan selama kurang lebih 2 jam dan selanjutnya dilakukan penilaian.

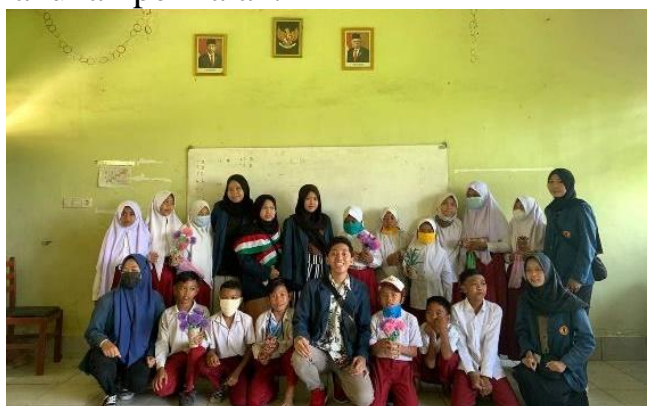

Gambar 3 Pelaksanaan Kegiatan Bimbingan Pembuatan Kerajinan Tangan

c) Pendampingan Class Meeting

Pendampingan class meeting merupakan salah satu program kerja dan kegiatan yang dilaksanakan oleh mahasiswa KKN Terpadu Unram 2021. Pendampingan class meeting dilaksanakan di SMP IT Riadussolihin di Desa Pare Mas. Pembimbingan Class meeting dilakukan dengan memberikan arahan kepada panitia penyelenggara yaitu anggota osis SMP IT Ryadussolihin untuk menyusun lomba apa 
saja yang akan diadakan di Sekolah, sistematika lomba, dan segala bentuk persiapan yang dilaksanakan. Mahasiswa KKN Terpadu Unram juga membantu mengambil alih perlombaan Lomba Cerdas Cermat yang dilaksanakan. Mulai dari membantu pembuatan soal cerdas cermat, penjurian dan pelaksanaan lomba cerdas cermat. Lomba cerdas cermat diikuti oleh 3 kelompok yang dimana masing-masing kelompok terdiri dari 3 orang dari perwakilan kelas 7, 8 dan 9. Pelaksanaan cerdas cermat berlangsung sangat meriah yang dimenangkan oleh kelompok $\mathrm{B}$ sebagai juara 1, kelompok $\mathrm{C}$ sebagai juara ke 2 dan kelompok A sebagai juara ke 3 . Kegiatan pendampingan lomba cerdas cermat terbilang berhasil dilaksanakandilihat dari segala rangkaian kegiatan sukses dijalankan.

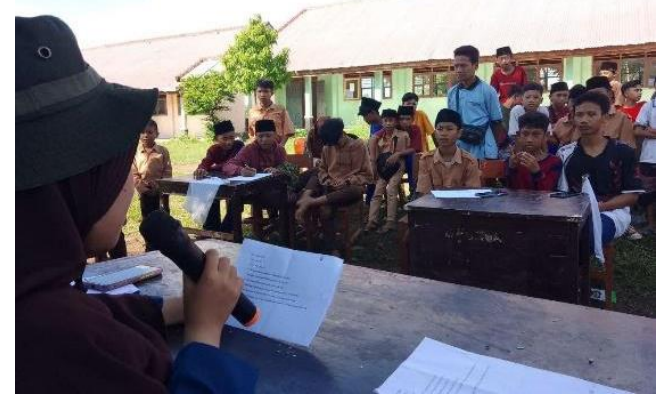

Gambar 4 Pelaksanaan Kegiatan Cerdas Cermat

\section{2) Rumah Belajar}

Program ini dirancang dengan tujuan untuk menjadi wadah tempat belajar serta meningkatkan pengetahuan anak-anak di Desa Pare Mas. Pembelajaran dilaksanakan di lokasi mahasiswa KKN Terpadu Unram. Beberapa program belajar yang disediakan yaitu belajar matematika yang dilaksanakan pada hari senin, membaca dan menulis pada hari selasa dan basic english pada hari rabu. Terakhir yaitu belajar mengaji yang dilaksanakan di musholla pada waktu magrib dan subuh.

a) Belajar Basic English

Pengajaran basic English dilakukan oleh mahasiswa KKN Terpadu Universitas Mataram yang berasal dari program studi Pendidikan Bahasa Inggris, pengajaran ini dilakukan satu kali seminggu pada hari rabu, jenis pengajaran yang diberikan mahasiswa KKN Terpadu kepada anak-anak yang berada di Desa Pare Mas yaitu belajar alphabet, number, dan introduction. Pembelajaran basic english dirasa penting untuk diajarkan kepada anak-anak di Desa Pare Mas, karena memiliki potensi wisata yang dapat menarik minat wisatawan lokal hingga mancanegara. Sehingga perlu dipersiapkan sumber daya manusia yang dapat mengoptimalkan potensi wisata yang dimiliki.

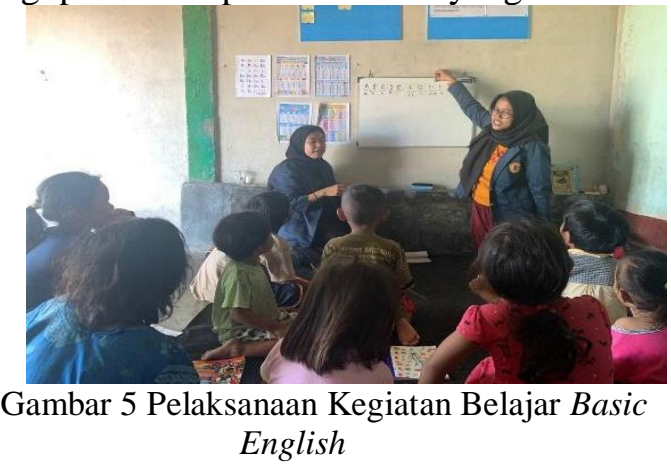

b) Belajar Matematika

Kegiatan ini diharapkan dapat meningkatkan kemampuan siswa dalam menghitung dan meningkatkan minat belajar siswa. Pengajaran matematika ini dilakukan oleh mahasiswa KKN Terpadu Universitas Mataram yang berasal dari program studi Pendidikan Matematika, pengajaran ini dilakukan satu kali seminggu pada hari senin, jenis pengajaran yang diberikan mahasiswa KKN Terpadu kepada anak-anak yang berada di Desa Pare Mas yaitu operasi penjumlahan, pengurangan, perkalian dan pembagian.

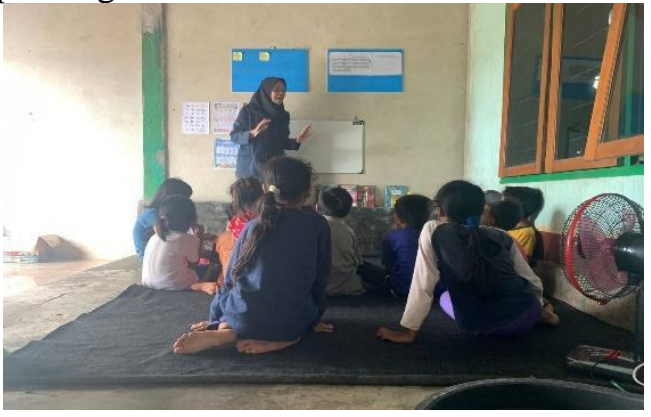

Gambar 6 Kegiatan Belajar Matematika

c) Belajar Membaca

Kegiatan ini dilaksanakan karena pentingnya kemampuan membaca untuk dikuasai. Membaca merupakan gerbang pertama untuk menuju proses pembelajaran yang lebih kompleks untuk menambah ilmu dan pengetahuan. Pengajaran membaca ini dilakukan oleh mahasiswa KKN Terpadu Universitas Mataram yang berasal dari program studi Pendidikan Bahasa Indonesia, pengajaran 
ini dilakukan satu kali seminggu pada hari selasa, jenis pengajaran yang diberikan mahasiswa KKN Terpadu kepada anak-anak yang berada di Desa Pare Mas yaitu menyusun kalimat dan belajar membaca buku bacaan dan buku cerita yang disediakan di lokasi KKN Terpadu Unram.

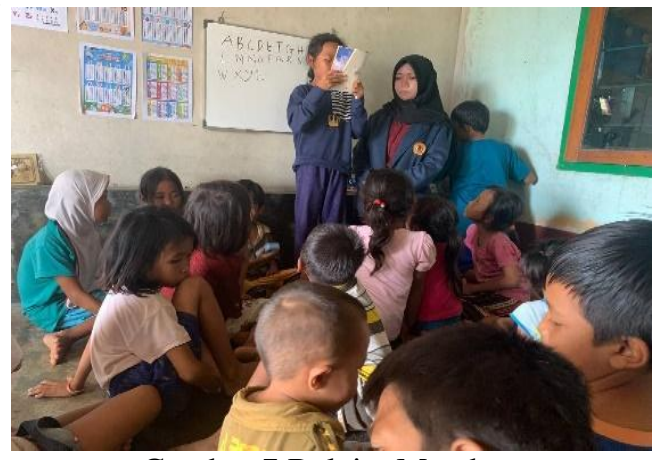

Gambar 7 Belajar Membaca

d) Belajar Mengaji

Kegiatan ini dilaksanakan untuk untuk mendukung dan menciptakan karakter anak ke arah yang lebih baik dan mengenal Tuhan-Nya. Pengajaran mengaji dilakukan setiap hari senin sampai minggu ba'da magrib dan ba'da subuh, jenis pegajaran yang diberikan mahasiswa KKN Terpadu kepada anak-anak yang berada di Desa Pare Mas yaitu mebaca Iqro', menyimak bacaan Al-quran, dan hafalan ayat-ayat pendek.

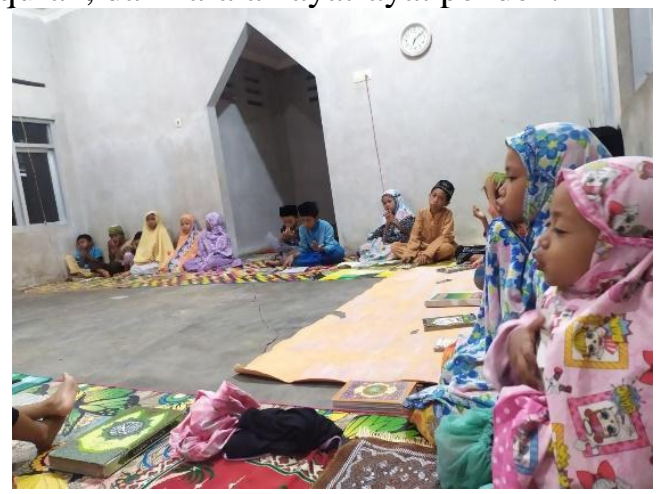

Gambar 8 Belajar Mengaji

\section{Kesimpulan}

Berdasarkan survei lapangan yang oleh mahasiswa KKN terpadu Universitas Mataram sejak bulan 20 November - 6 Januari. Ditemukan beberapa hal yang kiranya menjadi pokok permasalahan yang ada di Desa Pare Mas, dimana salah satunya yaitu terdapat pada sektor pendidikan. Karena pendidikan merupakan akar dari kehidupan, sehingga sektor ini perlu ditinjau dan diperhatikan dengan seksama untuk meningkatkan kualitas yang ada.

Program kerja yang dirancang dan dilaksanakan diantaranya yaitu Program Pengajaran di Sekolah dan Program Rumah Belajar. Program pengajaran di sekolah terdiri dari edukasi tanggap bencana, lomba mewarnai, pembimbingan kerajinan tangan, dan pendampingan kegiatan class meeting. Selain itu, dilaksanakan pula program rumah belajar yang terdiri dari kegiatan belajar basic english, belajar matematika, belajar membaca, serta belajar mengaji.

Seluruh kegiatan yang ada, ditujukan untuk membantu meningkatkan kualitas pendidikan yang ada serta menjadi wadah untuk meningkatkan pengetahuan dan keterampilan anak-anak di desa pare mas

\section{Ucapan Terima Kasih}

Terima kasih kami ucapkan kepada Dosen Pembimbing Lapangan yang telah memberikan arahan, bimbingan, serta motivasi dalam pelaksanaan KKN Terpadu, FKIP, Universitas Mataram di Desa Pare Mas, Kecamatan Jerowaru, Kabupaten Lombok Timur. Ucapan terima kasih juga kami sampaikan kepada seluruh masyarakat yang telah membantu kami dalam menyelesaikan kegiatan ini dengan baik dari awal hingga akhir serta kami mengucapkan terima kasih kepada temanteman KKN Desa Pare Mas yang sudah bekerja sama dengan baik sehingga kegiatan ini dapat terlaksana dengan baik dan lancar tanpa hambatan apapun.

\section{Daftar Pustaka}

Abdil, Nurul Satria, dkk. 2017. Pemberdayaan Masyarakat Kampung Notoprajan. Nganpilan, Yogyakarta. Dalam Program Pengembangan Jam Belajar Masyarakat. Yogyakarta: Artikel KKN UAD.

Sanjaya. Mega. 2016. Pengajaran dan Pendalaman Materi Pelajaran Bagi Anak Sekolah di Posko Kuliah Kerja Nyata (KKN). Di Desa Sukaharja Kecamatan Cikulur. Artikel KKN STAI La Tansa Mashiro.

Sugiyono. (2015). Metode Penelitian dan Pengembangan Pendekatan Kualitatif, Kuantitatif, dan R\&D. Metode Penelitian Dan Pengembangan Pendekatan Kualitatif, Kuantitatif, Dan R\&D, 130. 
Yulita, Wardhani, dkk. 2019. Pemberdayaan Masyarakat Miliran, Muja Muju, Umbulharjo Yogyakarta. Dalam Program Bimbingan Belajar Masyarakat. Artikel KKN UAD. 